\title{
MANDAT PEKERJA SOSIAL UNTUK MELAKUKAN ADVOKASI DALAM MEMBERIKAN PERLINDUNGAN TERHADAP TENAGA KERJA INDONESIA
}

\author{
Shelly Puspita Sari \\ Terapis di Pusat Layanan Tubuh Kembang Anak (YAMET) Tangerang Selatan \\ Email: shellypuspitasari92@gmail.com
}

Received: $18^{\text {th }}$ March 2018; Revised: $19^{\text {th }}$ April 2018; Accepted: $19^{\text {th }}$ June 2018

\begin{abstract}
There are potential social problems facing Indonesian Workers, ranging from violence in the workplace, unpaid wages and etc. The role of state is to guarantee safety and legal protection from various crimes threatening labor' life and survival.Social protection can be defined as any form of public policy and intervention undertaken to respond to various risks, vulnerabilities and tribulations, whether physical, economic, or social, especially those experienced by those living in poverty. But unfortunately, the government's attention is still considered less than the aspect of its implementation. Therefore, the article argues on the important of role of social workers in a form of advocacy in providing protection for Indonesian workers.
\end{abstract}

Keywords: social workers, advocacy, Indonesian workers, labor.

Abstrak. Masih banyaknya potensi permasalahan sosial yang dialami oleh Tenaga kerja Indonesia, yaitu mulai dari kekerasan di tempat kerja, tidak diberikan upah dan masih banyak lagi. Di mana seharusnya diberi perlindungan hukum oleh negara dan dijamin keselamatannya dari berbagai tindak kejahatan yang mengancam keberlangsungan hidup dan nyawanya. Sehingga dibutuhkan adanya perlindungan sosial. Perlindungan sosial dapat didefinisikan sebagai segala bentuk kebijakan dan intervensi publik yang dilakukan untuk merespon beragam resiko, kerentanan dan kesengsaraan, baik yang bersifat fisik, ekonomi, maupun sosial, terutama yang dialami oleh mereka yang hidup dalam kemiskinan. Namun sayang, perhatian pemerintah masih dianggap kurang dari aspek implementasinya. Karena itu, penting adanya peran dari pekerja sosial yaitu berupa advokasi dalam memberikan perlindungan terhadap tenaga kerja Indonesia.

Kata kunci: pekerja sosial, advokasi, tenaga kerja Indonesia. 


\section{Pendahuluan}

Industrialisasi di negara-negara dunia ketiga menyebabkan pasaran tenaga kerja di beberapa negara, termasuk Indonesia, terbuka bagi perempuan. Kebanyakan perempuan muda yang belum nikah cukup banyak terserap di industri-industri padat karya, seperti pabrik-pabrik, terpusat di sektor tekstil, pakaian jadi, elektronik, dan pengolahan bahan makanan. Berdasarkan penelitian Saptari (1997), lokalisasi industri di Jawa Tengah dan Jawa Barat banyak menyerap tenaga kerja perempuan.

Sayangnya, tingginya partisipasi perempuan dalam kerja publik ternyata tidak disertai jaminan terpenuhinya hak-hak buruh perempuan. Buruh perempuan merupakan yang paling rentan terhadap tindak kekerasan dari perusahaan, terutama mereka yang bekerja pada level bawah struktur organisasi perusahaan, yang biasanya memiliki tingkat pendidikan dan keterampilan yang rendah. Status kerja buruh perempuan sebagian besar merupakan buruh tidak tetap, dan rentan di-PHK. Selain itu, buruh perempuan memiliki kepentingan yang khusus terkait dengan fungsi reproduksi biologisnya yang harus dilindungi. Menurut data Sakernas tahun 2014, mayoritas buruh perempuan berstatus sebagai pekerja yang tidak dibayar.

Selain itu, bekerja sebagai buruh migran pun masih cukup rentan mengalami tindak pidana perdagangan orang atau trafficking. Direktur Eksekutif Migrant Care, Anis Hidayah, mengatakan dalam setiap tahun jumlah kekerasan dan kematian Tenaga Kerja Wanita di luar negeri semakin meningkat. Pada tahun 2009, jumlah tenaga kerja yang terkena kasus kekerasan mencapai angka 5.314. Di urutan pertama adalah kekerasan yang dialami TKW di Negara Malaysia sebesar 1.748. Posisi kedua, Arab Saudi sebesar 1.048 dan posisi ketiga Yordania sebesar 1.004 (viva.co.id, 28 Juni 2011).

Tenaga kerja perempuan yang mendapatkan kekerasan seksual secara langsung maupun tidak langsung akan menimbulkan trauma yang sangat berat dan tidak hanya itu, bila korban hamil, korban juga harus menanggung beban membiayai kehidupan anaknya seorang diri. Kekerasan yang dialami para tenaga kerja perempuan juga akan berdampak pada psikologisnya. Kejadian-kejadian tersebut menimbulkan trauma yang sangat berat bagi mereka dan banyak yang tidak mau lagi kembali untuk bekerja (Wawa, 2005).

Sementara itu, untuk kasus kematian mencapai 1.018 orang. Negara yang paling besar dengan jumlah TKW meninggal adalah Malaysia mencapai 687, sedangkan peringkat kedua Arab Saudi dengan angka kematian 221, dan yang menduduki urutan ketiga adalah Hongkong dengan jumlah 132 orang. Sedangkan tahun 2010 untuk kasus kematian mencapai angka 1.075 orang (viva.co.id, 28 Juni 2011). 
Melihat kondisi demikian, tenaga kerja Indonesia seharusnya diberi perlindungan hukum oleh Negara dan dijamin keselamatannya dari berbagai tindak kejahatan yang mengancam keberlangsungan hidup dan nyawanya. Perlindungan hukum bagi seluruh perempuan terhadap bentuk-bentuk kekerasan diatur dalam Undang-Undang Ketenagakerjaan nomor 13 tahun 2003. Dinyatakan bahwa "tenaga kerja adalah setiap orang yang mampu melakukan pekerjaan guna menghasilkan barang atau jasa baik untuk memenuhi kebutuhan sendiri maupun untuk masyarakat" (pasal 1 ayat 2 UU 13/2003). Indonesia juga telah memiliki UU nomor 21 tahun 2007 tentang Pemberantasan Tindak Pidana Perdagangan Orang yang diharapkan dapat menjadi payung hukum, perlindungan dan jaminan hak asasi perempuan yang menjadi korban trafficking, meskipun UU ini masih belum dapat mengakomodir persoalan trafficking yang terjadi di lintas batas wilayah Indonesia.

Pemerintah dalam hal ini melupakan pesan-pesan fundamental yang telah dituangkan ke dalam amanat konstitusi. Para tenaga kerja acap kali tidak mendapatkan perlindungan, bahkan semata-mata mereka hanya dijadikan komoditi. Kelalaian negara dalam memberikan perlindungan tenaga kerja Indonesia merupakan suatu kesalahan yang besar dan harus mendapatkan kritik tajam sehingga begitu akan menciptakan kebaikan.

Melihat perkembangan yang demikian, penting adanya advokasi. Advokasi sosial dimaksudkan untuk melindungi dan membela seseorang, keluarga, kelompok atau masyarakat yang dilanggar haknya. Karena itu, advokasi dapat kita lakukan terhadap tenaga kerja Indonesia dalam rangka pemberian perlindungan sosial. Perlindungan sosial merupakan sarana penting untuk meningkatkan perlindungan dampak kemiskinan dan kemelaratan yang dihadapi oleh kelompok miskin beserta anak-anak mereka (pekerja).

Perlindungan sosial merupakan elemen penting dalam strategi kebijakan sosial untuk menurunkan tingkat kemiskinan serta memperkecil kesenjangan multidimensional. Dalam arti luas, perlindungan sosial mencakup seluruh tindakan, baik yang dilakukan oleh pemerintah, pihak swasta, maupun masyarakat, guna melindungi dan memenuhi kebutuhan dasar, terutama kelompok miskin dan rentan menghadapi kehidupan yang penuh resiko, serta meningkatkan status sosial dan hak kelompok marginal di setiap Negara.

Perlindungan sosial dapat didefinisikan sebagai segala bentuk kebijakan dan intervensi publik yang dilakukan untuk merespon beragam resiko, kerentanan dan kesengsaraan, baik yang bersifat fisik, ekonomi, maupun sosial, terutama yang dialami 
oleh mereka yang hidup dalam kemiskinan. Karakter atau nuansa publik dalam definisi ini menunjuk pada tindakan kolektif yakni menghimpun dan mengelola sumber daya berdasarkan prinsip gotong royong dan kebersamaan yang dilakukan baik oleh lembaga-lembaga pemerintah, non pemerintah maupun kombinasi dari kedua sektor tersebut.

Karenaitu, penulis ingin merangkum seperti apa mandat pekerja sosial melakukan advokasi dalam pemberian perlindungan sosial terhadap tenaga kerja Indonesia. Hal ini penting, mengingat advokasi adalah salah satu tugas yang diemban pekerja sosial dalam mengatasi permasalahan-permasalahan sosial yang terjadi, termasuk dalam kasus tenaga kerja Indonesia seperti yang sudah dipaparkan di atas.

\section{Pembahasan}

Pengertian advokasi (Topatimasang, dkk, 2000) dalam bahasa Belanda yaitu advocaat atau advocateur berarti pengacara atau pembela. Karena itu, tidak heran jika advokasi sering diartikan sebagai kegiatan pembelaan kasus atau beracara di pengadilan. Dalam bahasa inggris, to advocate tidak hanya berarti to defend (membela), melainkan pula to promote (mengemukakan atau memajukan), to create (menciptakan) dan to change (melakukan perubahan).

Pengertian advokat menurut Undang-undang Nomor 18 Tahun 2003 tentang Advokat dalam pasal 1 ayat 1 dikatakan:

"advokat adalah orang yang berprofesi memberikan jasa hukum baik di dalam maupun di luar pengadilan yang memenuhi persyaratan berdasarkan ketentuan Undang-undang ini".

Dalam Edi Suharto (2004) dipaparkan beberapa teori advokasi dalam pekerjaan sosial. Menurut Kaminski dan Walmsley, advokasi adalah salah satu aktivitas yang menunjukkan keunggulan pekerjaan sosial dibanding profesi lain. Selain itu, banyak definisi yang diberikan mengenai advokasi. Beberapa di antaranya mendefinisikan advokasi adalah suatu tindakan yang ditujukan untuk mengubah kebijakan, kedudukan atas program dari suatu institusi.

Kutchins dan Kutchins (1978) mengatakan advokasi sesungguhnya termasuk yang tak dapat didefinisikan karena advokasi merujuk pada semua bentuk aksi sosial. Zastrow (1982) mengartikan advokasi adalah aktivitas menolong klien untuk mencapai layanan ketika mereka ditolak suatu lembaga atau suatu sistem layanan, dan membantu dan memperluas layanan agar mencakup lebih banyak orang yang membutuhkan. 
Schneider mengatakan "Advocacy was defined as an obligation of social workers to the legislative process" (2001:54). Dalam kaitan itu, pekerja sosial bertanggung jawab memastikan legislasi sosial dapat berlangsung efektif dan dilaksanakan. Advokasi juga digunakan untuk mempengaruhi dan bertindak secara kolektif untuk mempengaruhi perubahan sosial. Schneider (2001) mengatakan bahwa definisi terbaru mengenai advokasi harus terdiri dari beberapa kriteria yaitu kejelasan (clarify), dapat diukur (measurable), pembatasan (limited), berorientasi tindakan (action oriented), dan fokus kepada aktivitas bukan peranan atau hasil advokasi (focus on activity, not rules or outcomes of advocacy).

\section{Mandat Advokasi Pekerjaan Sosial}

Berdasarkan definisi di atas maka dapat dijelaskan bahwa advokasi pekerjaan sosial itu terdiri dari beberapa komponen (Edi Suharto, 2004), yang juga akan penulis masukkan unsur dari bagaimana perlindungan sosial terhadap tenaga kerja Indonesia, yaitu:

1. Eksklusif.

Terma ini digunakan untuk menjelaskan hubungan antara klien dan advokat yang menunjukkan hubungan tersebut hubungan tunggal, unik, terfokus kepada klien, tanggung jawab utama kepada klien dan berpusatkan kepada kebutuhan manusia.

Pekerja sosial yang melakukan advokasi kepada klien yaitu tenaga kerja Indonesia yang mengalami permasalahan sosial. Pekerja sosial mempunyai tanggung jawab penuh terhadap kliennya, sehingga pekerja sosial harus mengutamakan kepentingan pribadi klien dibandingkan kepentingan perusahaan, pelaku kejahatan maupun pemerintah selaku pembuat kebijakan.

2. Timbal balik (mutual).

Terma ini digunakan untuk menjelaskan hubungan antara klien dan advokat sebagai hubungan timbal balik, saling ketergantungan, kesamaan, bersama, berbagi tahap hubungan satu sama lain, pertukaran gagasan dan merencanakan bersama-sama, dan memiliki kebersamaan satu sama lain. Hubungan timbal balik bermaksud bahwa advokat tidak mendominasi atau menyusun agenda klien, sebab kebutuhan klien diberi perhatian yang khusus. Advokat bekerjasama dengan klien, dan mereka memprosesnya sesuai dengan kesepakatan yang disetujui bersama-sama. Termasuk 
dalam tema hubungan timbal balik ini adalah pemberdayaan sebagai nilai pekerjaan sosial utama.

3. Representasi.

Terma ini adalah berkaitan dengan orientasi tindakan dan menjelaskan aktivitas advokat dengan berbicara, menulis, atau bertindak bagi pihak lain, berkomunikasi atau pernyataan kepedulian terhadap klien.

Untuk permasalahan tenaga kerja Indonesia, biasanya kita memberikan perlindungan terhadap klien. Hal ini harus tersampaikan dengan baik kepada klien sehingga klien dapat merasakan manfaat yang sudah pekerja sosial kerjakan.

4. Klien

Dalam advokasi pekerjaan sosial, klien mendelegasikan kepada pekerja sosial untuk bertindak atas dirinya yaitu representation sebagaimana disebutkan di atas. Klien mungkin individu perorangan, kelompok kecil atau besar, persatuan masyarakat, populasi etnik tertentu, individu-individu dengan kesamaan karakteristik dan kepedulian.

5. Masalah penyebab

Masalah biasanya tunggal, kondisi atau masalah yang menyebabkan sejumlah orang berminat dan mendukung. Menurut Kotler, ada tiga jenis penyebab, yaitu:

a. Helping cause

Masalah pertolongan di mana advokat mencoba memberikan pertolongan, kenyamanan atau pendidikan kepada korban kesalahan bantuan sosial termasuk rumah perlindungan bagi wanita korban kekerasan atau perlindungan.

b. Protest cause

Tindakan protes, di mana advokat mencoba mereformasi institusi yang menimbulkan masalah sosial, mempersoalkan tingkah laku baru untuk memperbaiki kondisi, contohnya rehabilitasi lingkungan kumuh atau menuntut pemerintah mengalokasikan dana untuk pelayanan kesehatan mental berbasis masyarakat.

c. Revolutionary causes

Dalam hal ini advokat berharap dapat mengurangi institusi atau pihakpihak yang tidak mendukung perbaikan kondisi.

6. Forum 
Sebuah forum adalah majelis yang diorganisir untuk mendiskusikan isu, undang-undang, peraturan-peraturan, ketentuan-ketentuan, masalah publik atau penyampaian opini. Dua hal yang perlu dilakukan untuk melaksanakan forum:

a. Menetapkan seperangkat prosedur yang memandu peserta.

b. Mekanisme pembuatan keputusan

7. Sistematika

Advokasi pada dasarnya bersifat sistematik. Hal ini karena advokasi menerapkan pengetahuan dan keterampilan dalam suatu perencanaan. Keputusan tidak didasarkan kepada institusi melainkan berdasarkan keterampilan menganalisis situasi bersama klien.

8. Pengaruh

Pengaruh bermaksud memodifikasi, perubahan kesan, tindakan atau keputusan yang mempengaruhi klien. Beberapa aktivitas mempengaruhi termasuk mengorganisir kelompok klien, pembentukan koalisi, pendidikan publik, persuasi kepada administrator dan supervisor, berhubungan dengan pegawai pemerintah dan parlemen, pengumpulan data kajian, dan pemberian testimoni.

9. Pembuatan Keputusan

Terma ini merujuk kepada usaha mempengaruhi. Paling utama adalah advokat ingin melakukan perubahan dengan membuat keputusan berdasarkan rumusan dan penilaian mengenai berbagai aspek. Seperti alokasi, sumber daya, keuntungan, kelayakan dan akses pelayanan.

10. Tingkat ketidakadilan

Karakteristik terma ini adalah suatu tindakan, pendirian, institusi, peraturan atau keputusan tidak sesuai dengan undang-undang atau prinsip-prinsip keadilan.

11. Tidak responsif

Terma ini khususnya diterapkan kepada perorangan atau institusi yang dapat menjawab, mengakui, atau merespon, terhadap pertanyaan, permohonan, petisi, tuntutan, surat, komunikasi atau permohonan sesuai dengan masanya.

12. Sistem

Dalam konteks pekerjaan sosial, perkataan sistem merujuk kepada badan yang terorganisasi yang didesain dan bertanggung jawab untuk 
memberikan pelayanan kepada orang-orang yang layak, mendistribusikan sumber penegakkan hukum dan bertanggung jawab penuh dalam interaksi masyarakat dengan sistem sumber.

Litzelfener dan Petr (1997) mengatakan profesi pekerjaan sosial pada dasarnya melaksanakan advokasi klien berdasarkan tanggung jawab etika dan fungsi utama praktek pekerjaan sosial. Terdapat beberapa obligasi yang mendasari praktek advokasi yang dilakukan oleh pekerja sosial, antara lain:

1. Kode etik

Dalam kode etik tercantum nilai-nilai dan prinsip antara lain dinyatakan bahwa tujuan utama pekerja sosial adalah membantu orang dalam memenuhi kebutuhan dan ditujukan kepada pemecahan masalah sosial, menentang ketidakadilan sosial, menghargai harkat dan martabat manusia serta mempromosikan kesejahteraan umum masyarakat. Kode etik juga mencantumkan tentang perlunya pekerja sosial menyadari dampak arena dan kebijakan politik terhadap praktek yang karenanya perlu advokasi untuk perubahan kebijakan dan perundangan yang dapat meningkatkan kondisi sosial dalam memenuhi kebutuhan dasar manusia dan keadilan sosial.

2. Pemahaman pekerjaan sosial tentang Person-in Environment.

Profesi pekerjaan sosial mempunyai pendekatan yang unik dalam membantu orang tumbuh dan berkembang yaitu keyakinan bahwa perserikatan atau lingkungan sosial individual mempengaruhi kesejahteraan mereka secara langsung. Oleh sebab itu, dalam membantu individu dengan permasalahannya juga harus mampu mengintervensi secara efektif pada level masyarakat, daerah, nasional atau internasional.

\section{Nilai dan Karakteristik Advokasi Pekerjaan Sosial}

Nilai merujuk kepada keyakinan yang penting, dimensi yang penting yang ada pada individu dan kelompok, nilai dasar dalam advokasi pekerjaan soasial adalah

1. Hak dan martabat individu

Pekerja sosial penting untuk menjaga salah satu nilai penting yaitu hak dan martabat individu, baik untuk diri sendiri, klien maupun orang di luar pekerja sosial dan klien.

2. Pemberian suara kepada yang tiada kuasa

Memberikan suara kepada pihak yang memang tidak memiliki kuasa/lemah untuk membantu menyelesaikan permasalahan sosialnya. 
3. Penentuan diri sendiri

Memberikan nilai untuk dapat menentukan mengenai diri sendiri sebagai pekerja sosial. Sehingga dalam melakukan advokasi, pekerja sosial dapat menjadi diri sendiri dan menjadi pekerja sosial yang dapat menyelesaikan tugasnya dalam melaksanakan advokasi.

4. Pemberdayaan dan perspektif penguatan

Nilai dalam melakukan advokasi sosial adalah pekerja sosial juga harus mengedepankan pemberdayaan dan perspektif penguatan. Sehingga tidak hanya melihat dari kasusnya saja namun melihat bagaimana klien dapat menjadi kuat dan berdaya.

5. Keadilan sosial

Keadilan sosial merupakan nilai penting yang harus dimiliki oleh pekerja sosial karena setiap masalah yang ditangani harus memberlakukan asas keadilan sosial sehingga pekerja sosial dapat berlaku sesuai dengan kapasitasnya.

Berikut ini karakteristik advokasi pekerjaan sosial:

1. Berorientasi tindakan

Suatu advokasi sudah pasti berorientasi kepada tindakan untuk mencapai perubahan sesuai dengan fungsi dan peranan pekerja sosial.

2. Menentang Ketidakadilan

Pada dasarnya pekerjaan sosial sangat menentang ketidakadilan yang ada di dalam sistem sosial masyarakat.

3. Tidak Netral

Karakteristik lain advokasi pekerjaan sosial adalah para pekerja sosial tidaklah bersifat netral. Dalam hal advokasi, pekerja sosial berpihak kepada yang lemah, yang perlu dibantu melalui usaha advokasi.

\section{Penutup}

Tenaga kerja Indonesia masih rentan mengalami tindak pidana perdagangan orang atau trafficking. Buruh perempuan merupakan buruh-buruh yang paling rentan terhadap tindak kekerasan dari perusahaan, terutama mereka yang bekerja pada level bawah struktur organisasi perusahaan, yang biasanya memiliki tingkat pendidikan dan keterampilan yang rendah.

Tingginya permasalahan sosial yang muncul dan kurangnya implementasi 
kebijakan-kebijakan yang dapat menyelesaikan permasalahan sosial tersebut, maka dibutuhkan adanya advokasi yang dapat dilakukan oleh pekerja sosial.

Advokasi adalah salah satu aktivitas yang menunjukkan keunggulan pekerjaan sosial berbanding profesi lain. Advokasi adalah aktivitas menolong klien untuk mencapai layanan ketika mereka ditolak suatu lembaga atau suatu sistem layanan, dan membantu dan memperluas layanan agar mencakup lebih banyak orang yang membutuhkan.

Perlindungan sosial dapat didefinisikan sebagai segala bentuk kebijakan dan intervensi publik yang dilakukan untuk merespon beragam resiko, kerentanan dan kesengsaraan, baik yang bersifat fisik, ekonomi, maupun sosial, terutama yang dialami oleh mereka yang hidup dalam kemiskinan.

\section{Daftar Pustaka}

Kutchins, H. \& Kutchins, S. (1978). Advocacy and social work. Dalam G. Weber \& G. McCall (Eds.). Social scientist as advocates: View from the applied disciplines. Beverly Hills, CA: Sage.

Litzefelner, P. \& Petr, C. G. (1997). Case advocacy in child welfare. Social Work, 42, 392402.

Saptari, dkk. (1997). Perempuan Kerja dan Perubahan Sosial. Jakarta: Pustaka Utama Grafiti.

Schneider, R. L. \& Lester, L. (2001). Social Work Advocacy: A New Framework for Action. Belmont, CA: Brooks/Cole Thomson Learning.

Suharto, Edi. (2004). Isu-isu Tematik Pembangunan Sosial, Konsepsi dan Strategi. Jakarta: Badan Pelatihan dan Pengembangan Sosial.

Tiap Tahun, Kekerasan terhadap TKW Meningkat, diakses dari https://www.viva. co.id/berita/nasional/229833-tiap-tahun-kekerasan-terhadap-tkw-meningkat Topitimasang, dkk. (2000). Merubah Kebijakan Publik. Yogyakarta: Pustaka Pelajar. Undang-Undang Republik Indonesia Nomor 18 Tahun 2003 tentang Advokat. Undang-Undang Republik Indonesia Nomor 18 Tahun 2003 tentang Ketanagakerjaan. Wawa, Jannes Eudes. (2005). Ironi Pahlawan Devisa, Kisah Tenaga Kerja dalam Laporan Jurnalistik. Jakarta: Kompas. 